\title{
Nútímavæðing á niðurskurðartímum - opnun bráðageðdeildar við Hringbraut
}

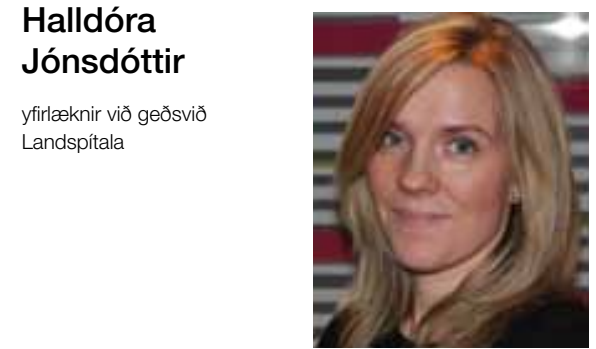

halldjon@landspitali.is

Umræða um heilbrigðismál hefur undanfarin ár einkennst af fréttum af niðurskurði, slæmum aðbúnaði, gríðarlegu álagi og flótta fagfólks úr landi. Við höfum lítið séð af jákvæðari fréttum, pví miður, en vissulega er heilbrigðiskerfið í próun prátt fyrir erfiða tíma síðustu ár. Á geðsviði Landspítala hefur verið skorið niður eins og annars staðar, en pó getum við stolt sagt að pað hafi orðið mikil próun í starfinu síðustu árin. Рað hefur farið fram innri skoðun á starfsemi geðsviðs og hvert beri að stefna í faglegu starfi par. Í nútímageðheilbrigðispjónustu er lögð áhersla á að pungi meðferðar og endurhæfingar fari fram úti í samfélaginu og á göngudeildum, en einnig á aukna sérhæfingu pjónustu. Á geðsviði hefur verið stofnað samfélagsgeðteymi, FMB-teymi, til að pjónusta pungaðar konur og fjölskyldur með ung börn, starf á endurhæfingarsviði hefur tekið miklum breytingum, meðal annars með eflingu pjónustu við ungt fólk með geðrofssjúkdóma og ný og nútímaleg réttargeðdeild hefur verið opnuð. Öflugar legudeildir fyrir bráðveika sjúklinga verða pó áfram nauðsynlegar pegar önnur úrræði duga ekki.

Nú á haustdögum opnar ný bráðageðdeild 32C við Hringbraut. Hafist hefur verið handa við breytingar á húsnæði móttökudeildar 32C með tilliti til parfa nýju deildarinnar sem er einskonar geðgjörgæsludeild. Á deildinni voru áður 17 rúm (auk tveggja bráðaplássa), en par verða nú 10 einmenningsherbergi (auk tveggja bráðaplássa) í tveimur kynjaskiptum álmum. Deildin er öll miklu rýmri en áður, með fleiri dag- stofum og herbergjum sem nýtast meðal annars til að róa órólega sjúklinga. Lögð er áhersla á öryggi sjúklinga og starfsfólks og á betri pjónustu í aðlaðandi umhverfi. Eitt af markmiðum starfsins á nýju deildinni er að draga úr truflandi atferli og ofbeldishættu og bæta pannig pjónustu við bráðveika sjúklinga. Um leið skapast tækifæri til að bæta pjónustu við aðra inniliggjandi sjúklinga, par sem öryggi á öðrum deildum eykst og vonandi svigrúm starfsfólks, pegar peir sjúklingar sem eru mest krefjandi dvelja á nýju bráđageðdeildinni.

Bráðadeildin mun veita sérhæfða einstaklingsmiðaða skammtímapjónustu fyrir sjúklinga sem purfa aukinn stuðning í öruggu umhverfi. Dæmi um sjúklinga sem deildin nýtist fyrir eru sjúklingar sem eru hættulegir sjálfum sér, öðrum og umhverfi, sjúklingar sem eru í verulegri strokhættu, peir sem eru ófyrirsjáanlegir, með mikla hegðunartruflun eða markalausa hegðun. Helstu kostir slíkrar deildar eru aukin sérhæfing sem leiðir til bættrar pjónustu fyrir pá allra veikustu og aukið öryggi sjúklinga og starfsfólks, en einnig skýrara verklag, bæði á nýju deildinni og á móttökudeildunum. Einstaklingar í bráđu geðrofi, alvarlegu örlyndi og mikilli sjálfsvígshættu purfa sérhæfða meðferð, pað parf að tryggja peim ró og draga úr áreiti til að bataferlið gangi betur og hraðar.

Móttökugeðdeildir við Landspítala hafa verið reknar með sama sniði í fjölda ára. prjár almennar móttökudeildir og ein fyrir einstaklinga með tvígreiningar, pað er geðræn vandamál og alvarlegan fíknisjúkdóm. Gangarnir par sem veikustu sjúklingarnir dvelja eru pröngir og engin rými önnur en herbergi sjúklinga. Í gegnum árin hafa starfsmenn heilbrigðispjónustunnar ef til vill ekki beint athyglinni nægilega að pví hvernig sjúklingum líður inni á legudeildum, hvernig umhverfið er. Upplifa inniliggjandi sjúklingar öryggi, geta peir fundið næði og ró, stuðlar umhverfið að bættri líðan? Rannsóknir hafa sýnt að meiri prengsli, stöðugt áreiti og skortur á „friði og ró" og persónulegu rými, eru pættir sem auka hættu á ofbeldi á geðdeildum., ${ }^{1,2}$ Раð er löngu tímabært að bæta aðbúnað og pjónustu við bráðveikt fólk í erfiðu geðrofsástandi og pað gerum við til muna með sérhæfðri legudeild fyrir pennan hóp.

Fyrirmyndin að deildinni er sótt til Bretlands, en par hafa slíkar deildir verið starfandi í 30 ár og verið í stöðugri próun til að mæta aðstæðum og pörfum á hverjum stað. ${ }^{3}$ Í undirbúningi að opnun nýju deildarinnar hefur starfsfólk heimsótt geðgjörgæsludeildir í Bretlandi og sérfræðingar paðan hafa sótt okkur heim og miðlað af sinni reynslu, auk pess að veita mikilvæga ráðgjöf um húsnæði nýju deildarinnar og pjálfa starfsfólk hennar.

Að ráđast í breytingar og kostnaðarsamar endurbætur á deildum Landspítala á tímum aðhalds og niðurskurðar er ekki einfalt mál pótt viljinn sé fyrir hendi. Pað er í raun ógerningur án utanaðkomandi stuðnings og aðstoðar. Með átakinu „Á allra vörum" verður safnað fé til að pessi nýja bráðageðdeild geti orðið að veruleika. Söfnunarátakið hefst 12. september og stendur til 26. september. Við erum ákaflega pakklát fyrir að fá pennan góða stuðning og pað er mikið tilhlökkunarefni að hefja starfsemi í húsnæði sem mætir nútímakröfum fyrir geðgjörgæsludeild. Deildin verður pó áfram í próun næstu árin, í takt við parfir sjúklinga og próun samfélagsins.

1. Kumar S, Ng B. Crowding and violence on psychiatric wards: explanatory models. Can J Psychiatry 2001; 46: 433-7.

2. Virtanen M, Vahtera J, Batty GD, Tuisku K, Pentti J, Oksanen $\mathrm{T}$, et al. Overcrowding in psychiatric wards and physical assaults on staff: data-linked longitudinal study. Br J Psychiatry 2011; 198: 149-55.

3. Beer DM, Pereira S, Paton C. Psychiatric Intensive Care 2nd edition. Greenwich Medical Media London, 2008.

Modernising when downsizing - Opening a Psychiatric Intensive Care Unit at Landspítali Halldóra Jónsdóttir, $\mathrm{MD}, \mathrm{PhD}$, psychiatrist, Division of Psychiatry Landspítali University Hospital 